\title{
Trusmi's Written Batik Manufacturer Industry And Its Impact On Trusmi's Batik Written Creator In The Village Trusmi Kulon Cirebon
}

\author{
Ai Nety Sumidartini \\ The STIAMI Institute of Social Sciences and Management \\ Correspondent: answara06@yahoo.com
}

Submitted : September 25,2020 Revised : October 17, $2020 \quad$ Published $\quad$ October 31, 2020

\begin{abstract}
Batik industry is now growing. Likewise with batik Trusmi that development is now growing rapidly. Revenue is a consequence or impact of the development of batik industry. Revenue Trusmi batik artisans, can be used for the basic needs of both basic needs and the needs of batik artisans in the business of making batik and batik artisans revenue also used for industrial development or business Trusmi batik. The problems discussed in this esearch on the impact of batik artisans Trusmi revenue as a result of the development of batik industry Trusmi. With the goal, which is to determine the revenue impact of batik artisans Trusmi batik industry development. The method used in this research is using descriptive qualitative method with the approach used approach SWOT analysis (Strength, Weakness, Opportunity, Threath). Data collected by using observation and in-depth interviews with batik artisans Trusmi and also the village, as well as gathering documentation in the form of images and small notes. Results of research conducted by the researchers, it is known that income Trusmi batik artisans used for a variety of needs, not only for the basic needs of batik artisans but is also used to develop the Business of making batik. By using SWOT analysis of the impact of this revenue is not only powerful, but also has the disadvantage of not yet arranged neatly on the financial statements batik business, and there were also threats, in the form of batik competition from other regions. While the strength of itself is able to carry on business batik and opportunities that can develop the business of making or write Trusmi batik industry. With the aim to maximize profits and the opportunities and minimize weaknesses and threats to the batik artisans need to develop the business by using a strategy of differentiation.
\end{abstract}

Keywords: Writing batik in Trusmi Village

\section{INTRODUCTION}

The current national development policy refers to the development of all sectors with the direction of overall regional development all corners of the archipelago. The direction for this national development is to increase the national economy, increase the field work so as to reduce the unemployment rate, reduce the poverty level, and increase income per capita an important stage in improving the welfare of society, namely through industrialization.1 Industry is an activity to process or process goods using facilities and equipment, such as machinery.2 Development of regional industries is a strategic step regional development. In Indonesia, the industrial sector is divided into four classifications, namely: large industry, medium industry, small industry, and industry household. The definition of the four industrial sectors is seen from the number of workers according to the Central Statistics Agency (BPS), namely: Industry large, medium-sized industries, small industries, and home industries. 3 One of the home industries, small industries and medium industries in Indonesia is a batik craft industry. In Indonesia, batik was originally produced in Yogya and Solo, but now batik making or the batik industry can be found easily like in Pekalongan, Bali, Papua, 
Trusmi's Written Batik Manufacturer Industry And Its Impact On Trusmi's Batik Written Creator In The Village Trusmi Kulon Cirebon

Sumidartini

Cirebon and others. One of the Indonesian batik handicraft industries is Cirebon, especially the region Trusmi.Batik is a hallmark of Indonesia, Indonesian culture and is also the identity and identity of the Indonesian nation.

is also a craft that has high art and has existed since ancient times. Even UNESCO (United Nations Educational, Scientific, and Cultural Organization) decided that Indonesian batik is a world heritage, which was awarded on October 2, 2009, following the submission from UNESCO (United Nations Educational, Scientific, and Cultural Organization) the development of batik is currently growing and increasingly The development of the Indonesian batik industry is very rapid and not only limited to clothing products, but nowadays there are many forms modification of various household needs originating from batik, such as bags, shoes, sandals, headscarves and others.Trusmi is the industrial center batik in Cirebon. The development of the batik industry in Cirebon has been very developed, this can be seen from the number new showrooms that have sprung up in the Panembahan, Trusmi and Plered areas. Written batik is one of the batik products produced in Trusmi. The development of written batik is increasingly developing, many tourists are familiar with Trusmi's written batik. Besides that, batik craftsmen in Nowadays more and more, almost every house in Trusmi, especially women, is a batik craftsman. The existence of the batik craftsman profession today is almost a job that has long been abandoned by many people, because of skill or the skills required are not proportional to the income earned from working as a batik craftsman while making batik someone or a craftsman requires special skills that are not owned by everyone, so that only from the skilled hands of the craftsmen We can enjoy a cultural work of high artistic value. Trusmi's written batik is a cultural work that still exists today accepted by the community. Most of the batik craftsmen Trusmi in Plered sub-district, Cirebon Regency are still surviving, although the resulting product experiences ups and downs. Based on these problems, it can raise questions, namely "How is the development of Trusmi's batik industry in Cirebon and how is the impact of the development of Trusmi's written batik on the craftsmen's incomeBatik Trusmi? How is the development strategy for the Trusmi written batik industry that can increase the income of written batik craftsmen Trusmi? "The purpose of this study is to determine the development of the batik industry, Trusmi Cirebon, and its impact the development of written batik on the income of Trusmi Cirebon written batik craftsmen and to find out the development strategy of the Trusmi written batik industry to increase the income of Trusm batik craftsmen.

\section{METHODS}

The research methodology used is a qualitative research method using the SWOT analysis approach. The data source used is a primary data source in the form of interviews with research subjects and secondary sources as additional data to strengthen primary data.Data collection techniques used were interview data collection techniques, observation and documentation. The data analysis technique used is a non-statistical data analysis technique with a data analysis process, namely data reduction, data exposure, and drawing conclusions and data verification, and testing the validity of qualitative research data is to do triangulation.

\section{RESULTS AND DISCUSSION}

In general, industry essentially means a company that carries out operations in the field of economic activity which is classified as a sector Meanwhile, according to Law Number 3 
Trusmi's Written Batik Manufacturer Industry And Its Impact On Trusmi's Batik Written Creator In The Village Trusmi Kulon Cirebon

Sumidartini

of 2014 concerning industry, the definition of industry is all forms of economic activity which processes raw materials and/or utilizes industrial resources to produce goods that have added value or more benefits high, including industrial services. Batik is one way of making clothing materials. In addition, batik is a textile craft that is familiar to Indonesian people, it is even used as a symbol of the Indonesian nation. In the Big Indonesian Dictionary, batik is a printed cloth made specifically by writing or explaining wax (wax) on the cloth, then processed in a certain way.Based on the etymology, batik comes from the Javanese language, namely batik consists of a series of words mbat and tik. Mbat in the language of services means as ngembat or throws many times, while tik comes from the word dot. So, making up means throwing dots repeatedly on the cloth. So that the end of the form the points coincide to form a line. In addition, batik also comes from the word mbat which is short for the word make, meanwhile Tik is a point. According to the manufacturing process, it is divided into three (3) types, namely written batik, printed batik, and combination batik, namely written batik.with printed batik. The development of materials and technology has made the development of batik very diverse, such as fine and coarse written batik, batik stamp, batik screen printing (screening) and printing, or a combination of these processes. Even so, screening products cannot be classified as sebagai is a batik but it is called batik motif textile or batik printing.

A craftsman or craftsman according to the Big Indonesian Dictionary is a person who is diligent or works hard to improve his work. Or It can also be said that a craftsman is a person whose job or profession is making handicrafts. Craft is an item that is produced through hand skills, for example mats, wickerwork and so on. The concept of development and development income can be interpreted as the progressive and continuous means a change that is progressive (advanced, increasing and deep) and is continuous. According to Reni Akbar Hawadi development broadly refers to the whole process of change from the potential that is possessed both in the quality of abilities, characteristics, and new features. Development is not limited to the notion of growing growth, but also in it a series of changes that take place continuously and are permanent. According to the author, the development of written batik is a change is advanced, increasing and also deep and takes place continuously and remains in the activities of the written batik industry. Development of written batik can be seen from various aspects, namely, including: Capital, labor, production and marketing. Income (income) includes both income and Revenue is income arising from company activities which is commonly known as sales, service income, interest, dividends, royalties and rent. the total amount of money received by a person or household during a certain period of time. Meanwhile, income for entrepreneurs is residual after the total number of recipients is deducted by all production costs.

SWOT stands for (Strength, Weaknesses, opportunities, and Threath). SWOT analysis is a systematic identification of strengths and weaknesses of the organization and the opportunities and threats of the external environment. SWOT analysis is a form of situation and condition analysis which is descriptive (provides an overview) that is being faced or that might be faced by an organization or company.This analysis is expected to produce long-term plans by means of overcoming or reducing threats and weaknesses. This analysis is over tends to produce short-term plans, namely improvement plans.The SWOT analysis method is considered as the most basic method of analysis, which aims to see a topic or problem from four sides different. The results of the SWOT analysis are directions or recommendations to 
Trusmi's Written Batik Manufacturer Industry And Its Impact On Trusmi's Batik Written Creator In The Village Trusmi Kulon Cirebon

Sumidartini

maintain strength and increase the benefits of existing opportunities exists, by reducing weaknesses and avoiding threats.

The development of written batik, especially in the Trusmi Kulon area, is generally increasing, which is marked by the increase in the production of written batik with this, the batik craftsmen Trusmi Kulon never stop producing hand-written batik. The development of written batik when viewed from various aspects, namely:

1. Capital. The majority of written batik craftsmen in Trusmi Village have capital that comes from their own capital and is very limited, this is because most written batik craftsmen are home industries. which do not have much capital. As for some craftsmen who have large capital so that these craftsmen have their own shop or showroom. According to Mr. Hadirman, who is one of Trusmi's written batik craftsmen, in the making of written batik cannot be estimated. This is due to the gradual making of written batik, there are those who make motifs, fill in batik, and others. So, it always requires additional capital for making written batik. If the order or production increases from the results of Interview with Pa Karno (batik craftsman concurrently head of Trusmi market) on Saturday, 6 August 2018 and Interview with Mr. Ismaya (batik craftsman)On Saturday, August 6 2018, the capital to make hand-written batik will also increase.

2. Labor. The labor referred to here is the batik worker. A batik worker is someone whose job is to make batik at a batik craftsman. Originally a worker or workers in Trusmi Kulon Village come from Pekalongan, Central Java Province, but currently, especially batik workers are nativeAlthough there are still some workers who come from Pekalongan, the village is not as many as in the past. Seiring as time went on the number of batik workers was increasing. This is due to the increasing demand for batik. So that it takes workers batik much more.

3. Production. Initially batik craftsmen in Trusmi produced batik only for the court, not for many groups. But over time Until now, craftsmen produce batik not only for the kings of the palace, but for all people. So that work as a craftsman this batik is used by some people as a business venture. The production of written batik in Trusmi Kulon Village from year to year experiences increase or development very rapidly. This can be seen from the people's interest in Trusmi's written batik. So that the demand for the production of batik Trusmi is increasing.

4. Marketing. Interview with Mr. Kuwu (as a member of Trusmi Kulon Village) on Wednesday, 3 August 2018 Interview with Mr. Kuwu (as apparatus of Trusmi Kulon Village) on Wednesday, 3 August 2018 Interview with Mr. Ismaya (a batik craftsman) on Saturday, 6 August 2018 In general, the marketing used by written batik craftsmen in Trusmi Kulon Village, Cirebon Regency is to market it by mouth kemulut. The marketing of written batik is currently experiencing a very rapid development. Batik Trusmi is currently not only marketed in Cirebon area only, but there are several large craftsmen who have branches in other big cities, such as Jakarta and Yogyakarta marketing is expanding. In addition, there are several large hand-written batik craftsmen whose marketing has reached several other countries The development of marketing has also increased, namely by providing it by the government in the form of a batik market at a fixed rental price This batik market is devoted to home industry batik craftsmen who do not have a batik showroom or shop. Batik craftsmen can market 
Trusmi's Written Batik Manufacturer Industry And Its Impact On Trusmi's Batik Written Creator In The Village Trusmi Kulon Cirebon

Sumidartini

their products directly to consumers, with this hopefully an increase in income obtained by batik craftsmen.

In general, the development of written batik by Trusmi has an impact on the income of batik craftsmenwrote Trusmi. The impact is in the form of an increase in the economy of the Trusmi written batik craftsmen, namely, the income received by the written batik craftsmen Trusmi can now be used for various needs of Trusmi written batik craftsmen, from daily needs of written batik craftsmen to business needs.this batik making. Interview with Mr. Kuwu (batik craftsman) on Saturday, 6 August 2018, Interview with Mr. Ismaya (as apparatus of Trusmi Kulon Village) on Wednesday, 3 August 2018. The impact of the craftsmen's income, namely firstly, to meet the daily needs needed by Trusmi's written batik craftsmen and also their families.the need for food, clothing and even the need for boards. Second, Trusmi written batik craftsmen can continue the business of making Trusmi written batik,namely, Trusmi written batik craftsmen can buy the raw materials for the production of written batik. Written batik craftsmen can also fulfill the rights of batik workers, namely pay according to the work results of batik workers. Until batik craftsmen can also increase wages or income for batik workers. Trusmi written batik craftsmen can set aside some of the income they earn to save by Trusmi written batik craftsmen or it can be said.

From the results of the SWOT analysis, data shows that the income impact of Trusmi's written batik craftsmen has the power to pay up to an increase wages from the work of written batik workers, to meet the needs of Trusmi's written batik craftsmen and also their families, and to continue the batik business This Trusmi. The opportunity that is owned by the impact of the income of Trusmi written batik craftsmen is that Trusmi written batik craftsmen have the opportunity to developing the business of making Trusmi written batik so that this batik business can develop even more. As for the shortcomings of the impact of craftsmen's income Trusmi's hand-written batik, namely: Trusmi's written batik craftsmen have not been able to compile neat financial reports for Trusmi's hand-written batik, so There are no reports of costs incurred for production, and even there are no reports of income earned by written batik craftsmen Trusmi, while the threat from the income impact of Trusmi's written batik craftsmen is the presence of competitors from other regions. So that strategy used batik craftsmen Trusmi to maximize strengths and opportunities as well as minimize weaknesses and threats, can use with Trusmi's written batik business development strategy, the aim is to increase Trusmi's written batik business. Whereas if you look at the characteristics of the generic Michael R. Porter, the batik industry Trusmi uses a differentiation strategy. Based on the characteristics of the differentiation strategy, a unique and different product. According to one of the batik craftsmen, Trusmi's written batik is batik that has its own characteristics.be a differentiator between other Trusmi batik products. Because the making of hand-written batik takes a long time, this causes it The price is quite high compared to other batik. This is also one of the characteristics of the differentiation strategy with making written batik products that are varied and also different from others and unique. Another thing that distinguishes written batik from other batik is, from the result of image scratches produced by written batik. Images or motifs that are produced from written batik scratches are tidier or closer to neat if compared to other batik. As for other characteristics of differentiation, namely having a wider market. This Trusmi written batik has a wide market even abroad, because the products produced by Trusmi batik can be used by various consumers. 
Trusmi's Written Batik Manufacturer Industry And Its Impact On Trusmi's Batik Written Creator In The Village Trusmi Kulon Cirebon

Sumidartini

Written batik craftsmen used to develop Trusmi batik, namely by loyalty to customers or consumers to product quality From the analysis of internal factors and external factors, Trusmi's written batik does not only have strength and opportunity in batik Written batik but also written batik has the disadvantages and threats of Trusmi written batik. With competitors and substitute products for written batik Trusmi, according to the writer, batik craftsmen must continue to make observations, make new batik motifs innovations without leaving the hallmark of Trusmi written batik set aside income that will be used at a certain time as additional capital. In the way that Trusmi batik craftsmen do through save money, then Trusmi batik craftsmen can develop this Trusmi written batik making business. According to the author, the development of batik This writing has an impact on the income of Trusmi's written batik craftsmen. However, not all of these hand- written batik craftsmen can feel the impact this income, especially the home craftsmen who do not have much capital, so that the home craftsmen can only feel the impact The income from the development of written batik is only $25 \%$. Because the batik craftsmen have not been able to develop their business, they can only continue While batik craftsmen who already own a shop and can market their products, can feel the impact of their income. of the development of batik, which is $35 \%$. And the craftsmen who can feel the greatest impact of income are craftsmen who own a sowroom. or craftsmen who become craftsmen distributors. (Interview with Mr. Karno (batik craftsman) on Saturday, 6 August 2018 Interview with Mr. Ismaya (a batik craftsman) on Saturday, 6 August 2018 at home. This craftsman can feel the impact of income by $40 \%$, so that these craftsmen can continue to develop their batik business.

\section{CONCLUSSION}

The development of Trusmi's hand-written batik is currently increasing quite well, this is due to an increase in demand Trusmi written batik and also Trusmi batik today are increasingly known by the wider community, even to foreign countries. The development of Trusmi written batik This can be seen room four sides, namely the increase in capital for craftsmen to produce batik, the increase in the number of workers or batik laborers, the increasing number of Trusmi hand-written batik production and expanding marketing. The development of the written batik industry has had a positive impact for Trusmi written batik craftsmen. The impact is first, Trusmi written batik craftsmen can meet the daily needs required by Trusmi written batik craftsmen and their families, both food and clothing needs. Second, Trusmi written batik craftsmen can continue their business making Trusmi written batik. Third, Trusmi's written batik craftsmen can set aside a portion of the income received by the craftsmen. This Trusmi hand-written batik is for savings. With the aim, to develop the business of making written batik owned by Trusmi's batik craftsmen. carried out by Trusmi written batik craftsmen on the income impact of written batik craftsmen, namely by developing a batik-making business wrote Trusmi, using a differentiation strategy. Because, this batik is different from other batik, both from the manufacturing process, motif or prices and others. With a differentiation strategy, the craftsmen can increase the development of Trusmi written batik so that the Trusmi written batik craftsmen.

\section{REFERENCES}

Al-Quran Get Arabic and Translatin in Microsoft Word, Q.S. (16): 80

Desmita, (2010). Developmental Psychology, Bandung: PT Remaja Rosdakarya. 
Trusmi's Written Batik Manufacturer Industry And Its Impact On Trusmi's Batik Written Creator In The Village Trusmi Kulon Cirebon

Sumidartini

Gilarso, T(2003). Introduction to Microeconomics, Yogyakarta: Konisius.

Hamali Yusuf Arif (2016). Understanding Business Strategy \& Entrepreneurship Jakarta: Kencana.

Hartati Netty, Nihayah Zahratun, Shaleh Rahman Abdul and Mujib Abdul, (2005). Islam and Psychology, Jakarta: PT RajaGrafindo Persada.

Indonesian Accounting Association (1994). Financial Accounting Standards, Jakarta: Salemba Empat.

Kuncoro -Warisan Adiluhung Nusantara, Yogyakarta: CV ANDI OFFSET.

Restianti Hetti, (2010), Getting to know Quadra Batik.

Samuelson A. Paul, Nordhaus D William. (1992). Micro Economist, Jakarta: Erlangga.

Sukirno Sadono, (2010) Introductory Micro Economics Theory, Jakarta: Rajawali Perss.

Sun'an Muammil, Senuk Abddurrahman (2015). Regional Development Economics, Jakarta: Mitra Wacana Media.

Wulandari Ari. (2011). Batik Nusantara The Meaning of Philosophy, Making and Batik Industry, Yogyakarta: CV ANDI OFFSET.

http://badanbahasa.kemdikbud.go.id/kbbi/index.php

http://kbbi.web.id/rajin

http://www.kemenperin.go.id/download/518 